\title{
キャビテーション噴流による材料試験と表面改質
}

\author{
祖山 \\ 均*

\section{Material Testing and Surface Modification by Using Cavitating Jet}

by

\section{Hitoshi SOYAMA *}

Key words : Cavitation, Erosion, Material testing, Surface modification, Jet

\section{1 は じめに}

キャビテーションは, キャビテーション気泡の崩壊時 に数 GPa に及ぶ高衝撃圧を発生し, ${ }^{1,2}$ 流体機械に損傷, 振動，性能低下をもたらす. ${ }^{3)}$ なかでも，機械に致命的損 傷をもたらす激しいキャビテーション壊食 ${ }^{4)}$ の予測法の 確立が工業界から切望されており，その試みも行われて いる. ${ }^{5) \sim 8)}$ また，キャビテーションが有する金属材料に 損傷を与えるような強力なエネルギの有効利用が試みら れている.'

周知のように, キャビテーション壞食は, 流体力学, 材料工学, 電気化学的因子が複雑に絡み合った現象で あり ${ }^{10)}$ 機械的衝撃作用とともに腐食・化学作用も無視 できない.ここでは, 流速が大なる場合などキャビテー ション気泡の崩壊による機械的衝撃作用がキャビテーシ ヨン壊食の主因子である場合について主として取り上 げ, これを以下では単に壊食（エロージョン）と呼ぶこ とにする.

壊食の定量的予測は, キャビテーション衝撃力の計

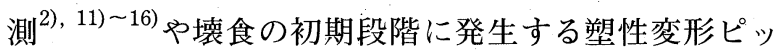

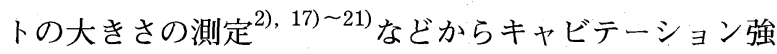
さを計測し，これと材料の耐キャビテーション性から各 条件に打ける壊食率を求めようとするものである。その ためには，材料の耐キャビテーション性を評価する材料 試験が必要不可欠である. 従来, キャビテーション材料 試験法としては振動式試験装置による ASTM G32 ${ }^{22)}$ が 使用されてきた。しかしながら，同規格では，回流水槽 試験などに比べて，試験時間が極端に短時間で済む利点 があるが，キャビテーションの発生機構が振動式である ために, 壊食の重要な支配因子である流速や寸法などの 影響を試験することができない. Lichtarowicz が考案 した ${ }^{23)}$ キャビテーション噴流を用いた壊食試験法は， 短時間で壊食を生じるとともに，ノズル上流側圧力およ び下流側圧力やノズル直径を変化させることにより，壊 食に係わる流速効果や寸法効果などを調べることが可能 である。これらの利点から，ASTM G2 摩耗と壊食に関 する委員会の $\mathrm{G} 02.10$ 固体と液体による壊食に関する分 科会により, ASTM G134 ${ }^{24)}$ として規格化された。
キャビテーション噴流は, キャビテーションの有効利 用の観点から, 流体力学的パラメータによりキャビテー ション衝撃力を制御できるので工業上の有用性が高い. 既にキャビテーションの利用例としては，油質の乳化， 超音波キャビテーションやキャビテーション噴流による 洗浄 $^{25)}$ などがあり, キャビテーション噴流はステンレス 鋼の残留応力改善にも応用されつつある. ${ }^{26), 27)}$ また, 近 年, 超音波キャビテーションを利用したアモルファズ金 属微粒子の生成 ${ }^{28)}$ やフラーレン C60 の合成などが成功 しており, キャビテーション噴流はキャビテーション強 さを任意に制御できるので，これらの分野への応用も検 討されよう。

ここでは, 筆者が日本学術振興会海外特別研究員と して, ASTM G134 の規格化に尽力した Lichtarowicz とノッティンガム大学において 2 年間にわたりキャビ テーション噴流に関する共同研究を行うなかで得た知見 について述べる. ASTM G134 の活用, あるいは，キャ ビテーション噴流の有効利用の一助としていただければ 幸いである。

\section{2 キャビテーション噴流}

$2 \cdot 1$ キャビテーション噴流の支配パラメータ

まず，キャビテーション噴流について簡単に述べる. キャビテーションとは, 流動する液体の低圧部分に液相 から気相が発生する局所的相変化が発生する現象である. 類似の現象に，沸騰および脱気があるが，沸騰は加熱に 起因する現象であり，脱気では流速がほぼ 0 であること から，これらとキャビテーションは区別される。キャビ テーション流れの支配パラメータであるキャビテーショ ン係数 $\sigma$ は, キャビテーション噴流のようなノズルある いはオリフィス流れの場合は, ノズル上流側圧力 $p_{1}$, 下 流側圧力 $p_{2}$, および, 試料水の飽和蒸気圧 $p_{v}$ から次式 のように定義される。

$$
\sigma=\frac{p_{2}-p_{y}}{p_{1}-p_{2}} \cong \frac{p_{2}}{p_{1}}
$$

なお, キャビテーション噴流では, $p_{1} \gg p_{2} \gg p_{v}$ であ るので, 式 (1)のように簡略化して表せる.

次に異なるノズル形状 $A, B$ (各々のノズル直径 $d$,

原稿受理 平成 9 年 8 月 5 日 Received Aug. 5, 1997

* 正会員 東北大学大学院工学研究科機械知能工学専攻 $\overline{7} 980-8579$ 仙台市青葉区荒巻字青葉, Dept. Machine Intelligence and Syst. Eng., Tohoku Univ., Aoba-ku, Sendai, 980-8579. 
流量係数 $c_{d}$ は, 添字 $A, B$ を付して示す) のノズル直径 について考えてみる。噴流の流量 $Q$ および噴流のパワー $P$ は，式 (2)，(3) で表される。

$$
\begin{gathered}
Q=\frac{\pi d^{2}}{4} c_{d} \sqrt{\frac{2 \Delta \rho}{\rho}} \\
P=Q \times \Delta \rho=\frac{\pi d^{2}}{4} c_{d} \sqrt{\frac{2}{\rho}} \Delta \rho^{1.5}
\end{gathered}
$$

ここで, $\Delta p$ は圧力差 $p_{1}-p_{2}, \rho$ は試料水の密度である. ノズル $A, B$ に扔いて, 圧力差 $\Delta p$ が一定, かつ, パワー $P$ が等しい場合は,

$$
d_{A} \sqrt{c_{d_{A}}}=d_{B} \sqrt{c_{d_{B}}}
$$

したがって

$$
d_{e}=d \sqrt{c_{d}}
$$

\section{$\left(d_{e}\right.$ : ノズル有効直径 $)$}

キャビテーション噴流が生じる壊食は, スタンドオフ 距離とともに Fig. 1 のように変化し, 壊食率はスタンドオ フ距離の増大とともに，二つのピークを有する。', 29) -31) なお，キャビテーション噴流では，流れはノズル上流側 角部からはく離し, スロート内部で再付着しないので, スタンドオフ距離は，ノズル上流側角部から衝突面まで の距離とする．壤食率が極大值を示すピークのうち，， ズルから離れた方のピーク（第 2 ピーク）がキャビテー ションの崩壊衝撃圧によるものであり，このスタンドオ フ距離を最適スタンドオフ距離 $s_{o p t}$ と呼び, $s_{o p t}$ はキャビ テーション係数によって変化する. Fig. 1 から明らかな ように, 最適スタンドオフ距離近傍に扑いて, 壊食量の ピークはノズル近傍のピーク（第 1 ピーク）に比べて比
較的平坦になっており, 最適スタンドオフ距離はスタン ドオフ距離に敏感ではない. ${ }^{2), 31)}$ この事実は; キャビテー ション噴流を利用する場合にスタンドオフ距離をシビア に制御する必要がないことを意味し，有効な利点である。 な打，第 1 ピークの壞食は，気中水噴流と同様に，分裂 した液塊による衝撃力などのキャビテーション崩壊衝撃 圧とは異なる機構によると考えられている。

Fig. 2 には, 最適スタンドオフ距離 $s_{o p t}$ とキャビテーシ ョン係数 $\sigma$ の関係を種々のノズル形状抢よび試験装置に ついて示す ${ }^{31) ~}{ }^{355}$ 四中，参考のために，コニカルノズル およびシリンドリカルノズルからの噴流のキャビテーシ ヨン長さ $L$ も併せて示す ${ }^{36)} s_{o p t}$ および $L$ は, ノズル有効 直径 $d_{e}$ で無次元化している. ノズル形状および測定部

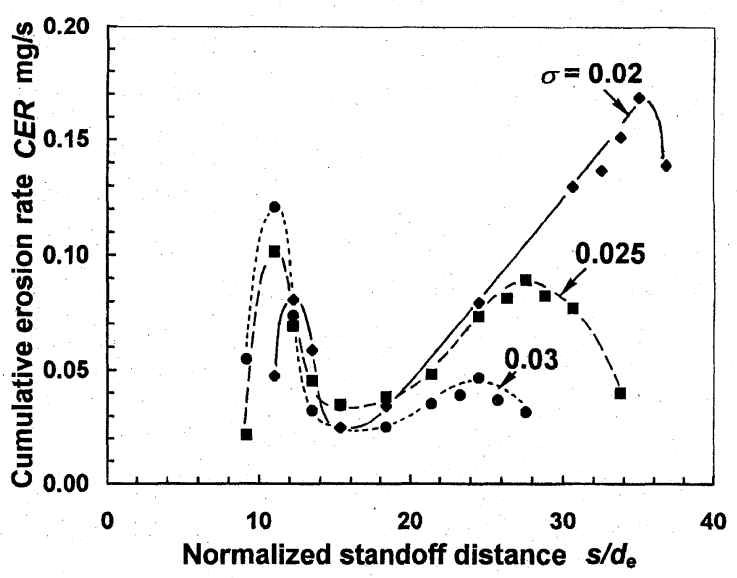

Fig. 1. Erosion rate changing with standoff distance (Aluminum alloy, $d=2 \mathrm{~mm}, p_{1}=12 \mathrm{MPa}$ ).

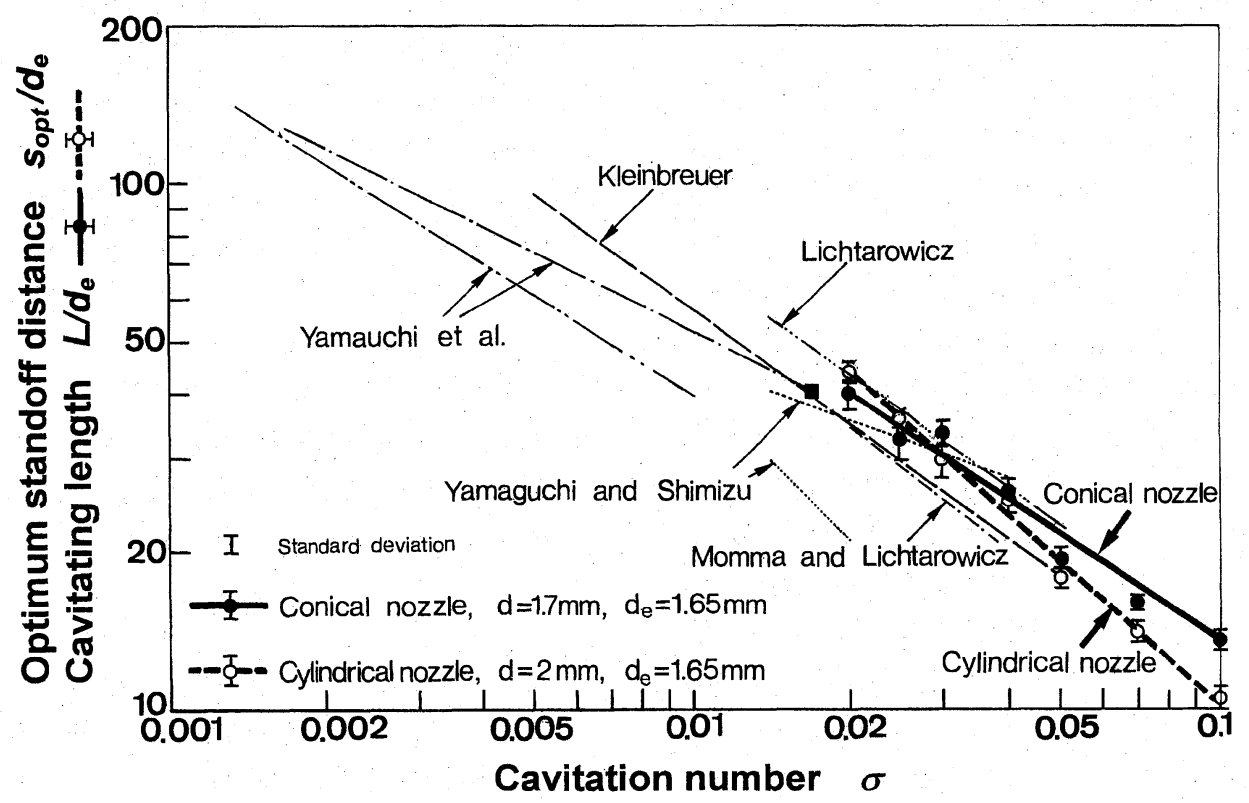

Fig. 2. Nondimensional optimum standoff distance and visible cavitating length as a function of cavitation number . 
寸法, および，試験条件が大きく異なっても， $s_{o p t}$ と $\sigma$ は両対数グラフ上で直線関係にあり，両者の関係は式 (6)によって表せる。

$$
\frac{s_{o p t}}{d_{e}}=c_{1} \sigma^{-n}
$$

ここで, $c_{1}$ と $n$ はノズル形状や測定部に依存する定数で 㐫る。なお，Lと $\sigma$ についても， $s_{o p t}$ と $\sigma$ と同様な関係が 成り立つ。 ${ }^{36)}$, 37 Fig. 2 と式 (6) より, 最適スタンドオフ距 離を概算できるので, これらはキャビテーション噴流を 活用する上で非常に有用である。

\section{$2 \cdot 2$ キャビテーション噴流の様相}

Fig. 3 は, キャビテーション噴流による衝撃压発生機 構の理解のために，PVDF フィルムを用いたセンサ ${ }^{16)} に$ より撮影した噴流衝突面で衝撃压を発牛している時のキ ヤビテーションの噴流の様相を示す。撮影には, 女ん光 時間 $0.4 \mu \mathrm{s}$ のアルゴンフラッシュランプを用いている。 図中, キャビテーションは, 微細なキャビテーション気 泡が集まった白い渦示状もしくはクラウド状に見えてい る。ノズルスロート内部もしくはノズル出口近傍から発 達する噴流まわりのせん断層の低压部にら旋渦キャビテ ーションが生じ, ${ }^{36)}$, 37)下流に移動するのに伴い，ら旋渦 キャビテーションが合体してクラウドキャビテーション となる。クラウドキャビテーションは，周期的に形成・ 放出される. ${ }^{38)}$ タラウドキャビテーションは試験片表面に 衝突し，衝突面中心から広がるにつれてリング洞キャビ テーションとして発達する。やがてリング渦キャビテー ションは四凸を生じて波打ち，その一部が衝笑面に金直 に渦コアを持つ状態で崩壤する（Fig. 3 中の挿入図参 照)。なお，白知印で示した位置にセンサの感土部分があ り，衝撃圧発生時にもキャビテーション気泡が仔在して
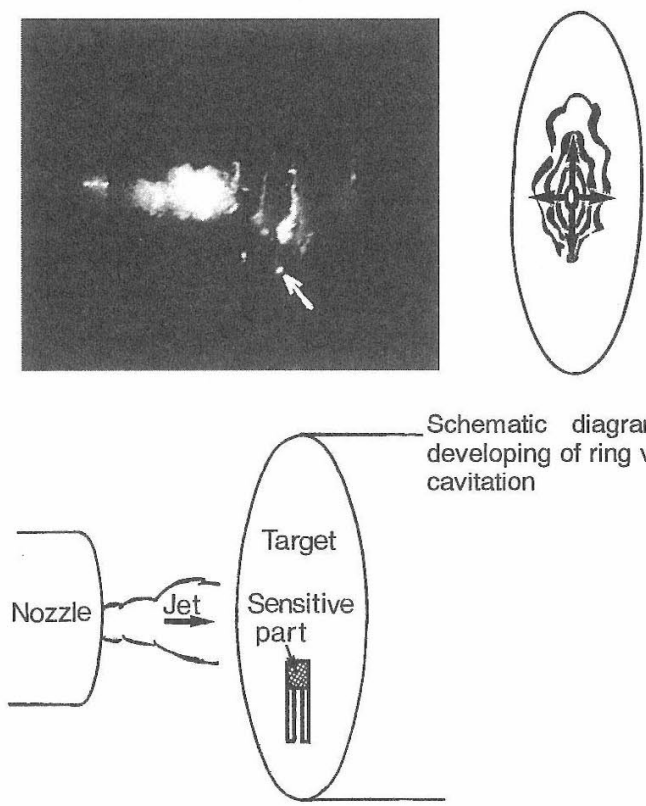

Schematic diagram of developing of ring vortex cavitation

Fig. 3. Impinging jet synchronized by PVDF sensor $\left(d=2 \mathrm{~mm}, \sigma=0.03, p_{1}=12 \mathrm{MPa}, s=40 \mathrm{~mm}\right)$.
いることが分る。このような微細気泡が集まったクラウ ドキャビテーションの崩壊時には，同じ大きさの単一気 泡に比バて著しく激しい衝撃」を発することが明らかに なっている.

Fig. 4 には，最適スタンドオフ距離におけるアルミニ ウム製試験片の典型的な壞食の様相を示す。主たる壊食 領域は，リング状を呈する。これは，前述したように， キャビテーションが噴流衝知面上でリング渦キャビテー ションとして発達した後に, 崩壊して壊食を生じるため である。壤食の初期段階においては，Fig. 4 に示すよう に，噴流衝突面の中心部は壊食を生じないが；壊食が発 達するにつれて，主壊食領域のリングの幅が内周方向括 よび外周方向へ掋大し，中心部にもやがて壊食を生じる ようになる。なお，衝營面に打けるキャビテーション係 数を考虑することにより式 (6) の $s_{o p t}$ とのの関係，打よび, 壊食痕がリング状である理由が説明される。

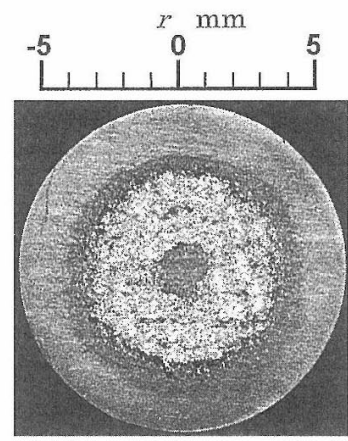

Fig. 4. Erosion pattern (Aluminum alloy, $d=0.4 \mathrm{~mm}$, $\left.\sigma=0.014, p_{1}=15 \mathrm{MPa}, s=17 \mathrm{~mm}, t=3 \mathrm{~min}\right)$.

翼形 $^{11), 20)}$ やポンプ ${ }^{4), 40), 41)}$ 䄯 $^{423,43)}$ などに生じる高壇食 性キャビテーションを詳細に高速度写真観察した結果， 激しい猿食は，キャビテーション噴流衝突面で見られる ような材料表面に垂直に渦コアを持つ特異な渦キャビテ ーションによって生じることが明らかにされている。周 知のように，キャビテーションは，そのタイプにより，初 生則や壤食強さが大さく異なる 食をもたらすタイプと同様なキャビテーションによって， 材料の評価試験を行うことが重要である。

\section{3 キャビテーション噴流による材料試験}

\section{3・1 キャビテーション噴流式壤食試験装置}

ASTM G134 "Standard Test Method for Erosion of Solid Materials by a Cavitating Liquid Jet” ${ }^{24)} の$ 試験装置 および方法について述べる。まず，Fig。 $5 ， 6$ には， ASTM G134 の試験装置概要とその測定部を示す。試料 水は約 $0.05 \mathrm{~m}^{3}$ のタンクに貯留し，これを最大吐出し圧 力 $21 \mathrm{MPa}$, 最大吐出し容量 $4.5 \ell / \min$ のプランジャーポ ンプで加压し，シリンドリカルノズルを通して試験部内 に設置した試験片に噴射する。試験片は，Fig. 7 に示す ような形状で, 噴流衝突面の直径は $12 \mathrm{~mm}$ である。， ズル上流側压力 $p_{1}$ および下流側圧力（測定部内の圧力） 


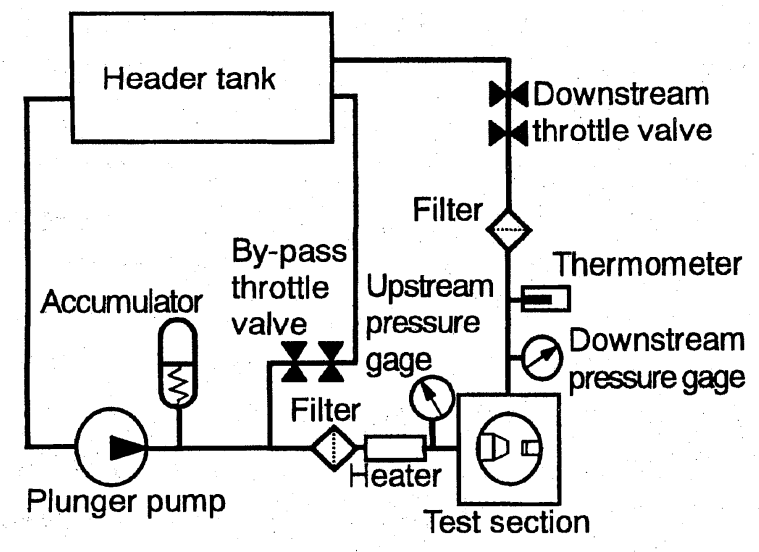

Fig. 5. Test loop.

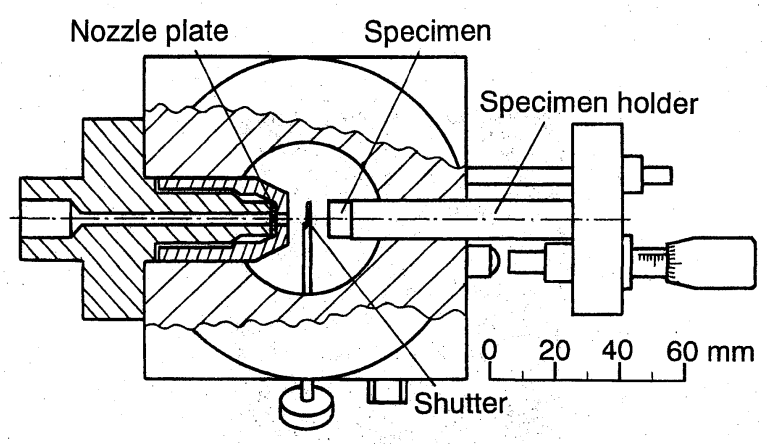

Fig. 6. Test chamber assembly.

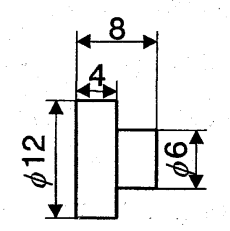

Fig. 7. Specimen.

$p_{2}$ は，それ乤れ流量調節弁によって制御し，圧力計によ り計測する。流量調節弁をノズル上流側, 下流側ともに 複数個使用することにより，弁における壊食が回避でき るとともに, 圧力の微調整が可能になる. Lichtarowicz は，下流側圧力調節弁に，キャブレタの原理を応用した 空気の調圧弁を利用した機構を採用している.

材料試験をする上で，再現性・信頼性を良くするため に最も重要な留意点は,ノズルである。 Fig. 8 には，シ リンドリカルノズル内部の詳細を示す，ノズルスロート 直径は $0.4 \mathrm{~mm}$ ，スロート長さは $1.22 \mathrm{~mm}$ である. ASTM G134 では，ドリルで穴あけ加工をした金属平板のノズ ルプレートをノズル押えに挟み込んでシリンドリカル， ズルとし，キャビテーション噴流の流量を決定するノズ

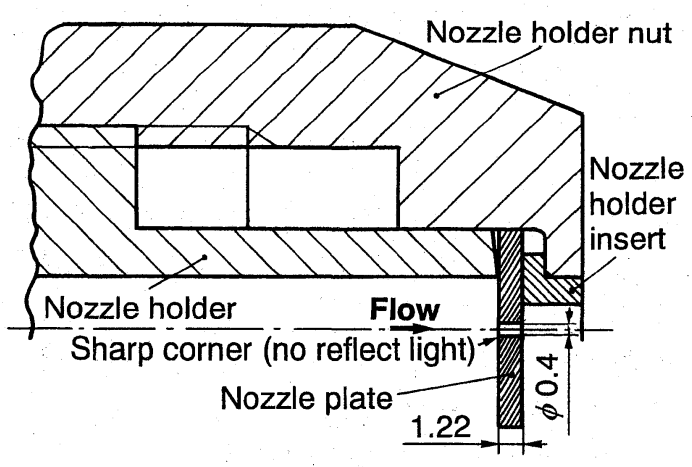

Fig. 8. Nozzle and nozzle holder.

ルスロート上流側角部は光学的にナイフエッジに仕上げ るように指示している。 この方法によると，比較的容易 にノズルスロート直径打よび流量係数が一定のノズルを 製作することが可能である。な打念のために，壊食試験 の前後には，必ず流量係数をチェックしてエロージョ ン・コロージョン等により，ノズル直径が変化していな いか確認する必要がある。複数個のノズルを用いて材料 試験を行う場合には，ノズル直径が等しく，かつ，流量 係数が等しいノズルプレートを用いるように， Lichtarowicz は強調していた。ノズルプレートを長時間 使用すると，ノズルプレートの下流側側面のノズルスロ 一ト周囲およびノズル押え治具にエロージョン・コロー ジョンが生じる。これはノズルスロート内部ではないの で，キャビテーション噴流の流量に直接影響しないが， 注意が必要である。この壊食対策および穴あけ加工の精 度を良くするために，ノズルプレートとノズル押え治具 の材質には Nitronic60 を使用している。

Fig. 9 には，参考までに，ノッティンガム大学が有す るノズル直径, 試験片および測定部の寸法が ASTM G134 規格の 5 倍の大きさの大型キャビテーション噴流壊 食試験装置の測定部を示す。? ${ }^{2), 35}$ 本装置は，耐キャビテ ーション被膜に用いられるコーティング剂等の通常の金 属材料に比べて粒子径が極端に大きい材料の壊食試験や キャビテーション噴流の流体力学的研究のために製作さ れたものである.

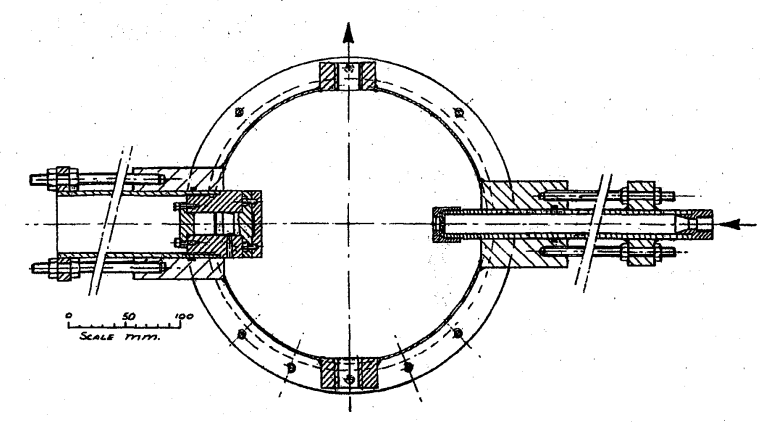

Fig. 9. Large cavitating jet rig. ${ }^{2), 35)}$ 


\section{$3 \cdot 2$ 材料の代表的壊食率}

周知のように, 壊食率は, 壊食の発達過程とともに大 きく異なる。壊食の初期段階に打いては，一般に，質量 欠損を生じずに塑性変形のみが繰り返され，やがて，疲 労破壊が生じて質量欠損を生じる。したがって，材料の 耐キャビテーション性を示す壞食率（壊食量の時間変化 率）は, Fig. 10 に示すように時間とともに変化し，大 略的に潜伏期, 加速期, 最大壊食期, 減衰期に大別され

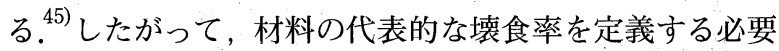
がある。壊食率は, Fig. 10 に示す質量損失の時間変化 曲線において, 各試験時刻における曲線の勾配で表され る壞食率（Instantaneous erosion rate）と，原点を通る 直線の勾配で表される累積壊食率 (Cumulative erosion rate）の二通りが考えられる. ASTM G134 では, 従来 用いられてきた壊食率（Instantaneous erosion rate）は 試験片の計量測定時間間隔に依存するのに対し，累積壊 食率は計量時間間隔にほとんど依存しないので，累積壊 食率が最大となる最大累積壊食率 (Maximum cumulative erosion rate）をを材料の耐キャビテーション性を表す 代表的壊食率とすることを強く推奨している.
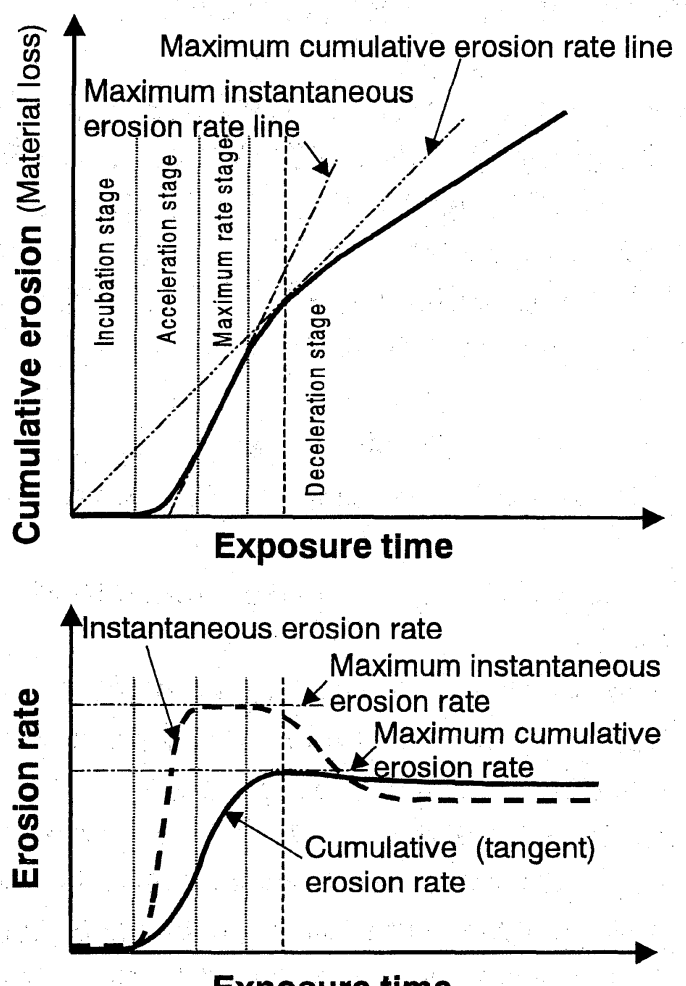

Exposure time

Fig. 10. Characteristic stages of cavitation erosion.

\section{$3 \cdot 3$ キャビテーション強さの主因子}

材料試験の試験条件設定の参考として, キャビテーシ ヨン強さに係わる主因子について記す. 最適スタンドオ フ距離に試験片を設置した場合, 主にキャビテーション 強さに係わる因子は，キャビテーション係数，ノズル上
流側圧力，ノズル下流側圧力，ノズル直径，温度などで ある。

Fig. 11 には，ノズル上流側圧力一定におけるキャビ テーション係数と累積壊食率の関係を示す。一般に，キ ヤビテーション係数が小なるほどキャビテーションが発 達し, キャビテーションの発生領域も大となるが, 累積 壊食率は $\sigma=0.014$ でピークを示す. 清水らも同様に $\sigma=$ 0.014 で壊食率が極大となることを報告している. ${ }^{46)}$

キャビテーション係数一定の場合には，ノズル上流側 圧力 $p_{1}$ が大なるほど壊食率は大となる。2, 24), 47)また， ASTM G134 では， $d=0.4 \mathrm{~mm}$ と規定されているが, 壊食 の寸法効果から予想されるように $d$ が大なるほど壊食率 も大となる. ${ }^{32), 47)}$ 試料水の温度 $t_{w}$ については, ASTM G134 では， $t_{w}=308 \pm 1 \mathrm{~K}$ としているが，振動式壊食試 験装置の結果と同様に, キャビテーション噴流による壊 食でも $t_{w} \cong 323 \mathrm{~K}\left(50^{\circ} \mathrm{C}\right)$ で壊食率は極大となる. $\left.{ }^{9}\right)$

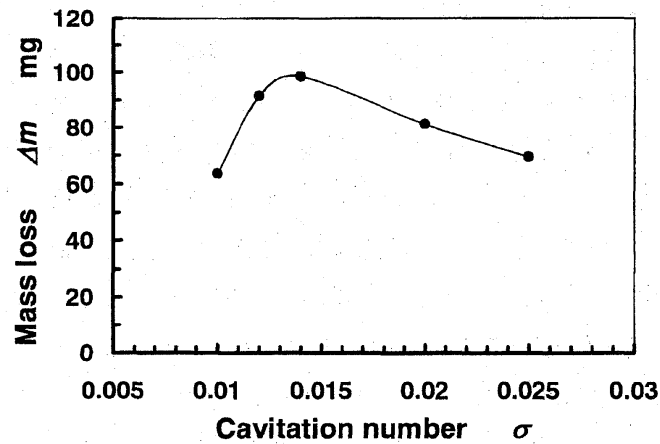

Fig. 11. Mass loss as a function of cavitation number (Aluminum alloy, $d=0.4 \mathrm{~mm}, p_{1}=20 \mathrm{MPa}, t=630 \mathrm{~s}$ ).

\section{4 キャビテーション噴流による表面改質}

\section{$4 \cdot 1$ 残留応力の改善}

筆者らは, キャビテーション衝撃力を有効活用したキャ ビテーション噴流による残留応力の改善を明らかにし， 続いて，平野らも同様な効果を確認している. ${ }^{27)}$ Fig. 12 に は, ASTM G134 規格のキャビテーション噴流壊食試験 装置を用いてピーニング加工したステンレス鋼製試験片 表面の残留応力分布を示す. 残留応力は, $\mathrm{X}$ 線回折法に より同一位置に扔ける三方向の応力成分を計測し，主応 力 $\sigma_{1}, \sigma_{2}$ を算出している. ${ }^{48)}$ 試験片表面は, 旋盤仕上げ であり, 引張残留応力が生じている. キャビテーション 噴流にさらすことにより, 残留応力が引張りから圧縮に 改善される. キャビテーション係数などのキャビテーショ ン噴流の支配パラメータを制御すると, 比較的低吐出し 圧力で，ごく短時間に残留応力を改善できる. 当然のこ とながら，長時間キャビテーション噴流にさらすと，い つたん圧縮に改善された残留応力がやがて引張り残留応

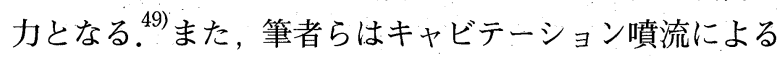
残留応力改善の実用化を目的として, 感圧紙法を用いて 種々の曲面上のキャビテーション衝撃圧分布 ${ }^{50)}$ を明らか 


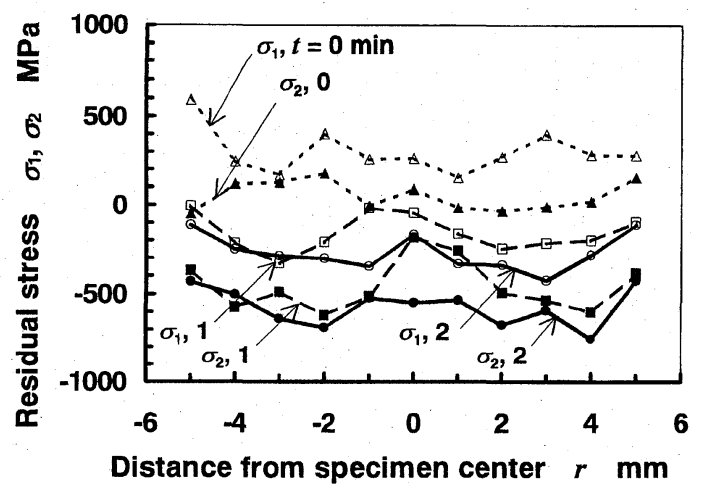

Fig. 12. Principal stress of residual stress changing with exposure time (SUS304, $d=0.4 \mathrm{~mm}, \sigma=0.01$, $p_{1}=20 \mathrm{MPa}, s=20 \mathrm{~mm}$ ).

にするとともに, キャビテーション・ノイズからキャビテ 一ション獖流の非定常特性 ${ }^{51)}{ }^{52)}$ を明らかにしている.

\section{$4 \cdot 2$ ，耐食性の向上}

キャビテーション噴流により炭素鋼の耐食性を向上で きる ${ }^{53)}$ Table I と Fig. 13 には, 電気化学的方法により 計測した腐食電位 $E_{\text {corr }}$ と分極曲線を示す。供試試験片 は $\mathrm{S} 45 \mathrm{C}$ で, 試験溶液は $0.1 \mathrm{~mol} / \ell \mathrm{Na}_{2} \mathrm{SO}_{4}$ 水溶液である. キャビテーション噴流による耐食性向上の比較試験とし て，(A) 噴流にさらさない場合，(B) キャビテーション が試験片に達しない噴流にさらした場合，(C) キャビテ ーション噴流にさらした場合の 3 条件について計測し た. $\mathrm{S} 45 \mathrm{C}$ の供試溶液中の腐食反応は, カソード分極曲 線で電位軸に平行している部分（この電流密度を拡散限 界電流密度という）が存在しているので，カソード支配 である. Table Iより, キャビテーション噴流にさらすこ とにより，腐食電位 $E_{\text {corr }}$ が卑にシフトしていることが分 る，カソード支配の腐食反応に打いて，腐食電位 $E_{\text {corr }}$ が卑にシフトすることは, 拡散限界電流密度, すなわち, 腐食電流密度が低下することを意味する。したがって， キャビテーション噴流は, 炭素鋼の腐食速度を低下させ て耐食性を向上させると言える。なお，アノード分極曲 線と腐食電位から求めた腐食電流密度を図中に矢印で示 すが，これもキャビテーション噴流にさらした場合 (C) は，A，B の場合に比べて腐食電流密度が小となること を示している. 最適なキャビテーション噴流の条件と効 果的な材料を選べば，キャビテーション噴流による飛躍 的な耐食性の向上が可能であろう.

キャビテーション噴流が炭素鋼の耐食性を向上させる

Table I. Erosion potential of carbon steel S45C.

\begin{tabular}{|c|c|c|c|c|}
\hline Condition & $\begin{array}{c}\text { Cavitation } \\
\text { number } \sigma\end{array}$ & $\begin{array}{c}\text { Upstream } \\
\text { pressure } \\
p_{1} \mathrm{MPa}\end{array}$ & $\begin{array}{c}\text { Standoff } \\
\text { distance } \\
\mathrm{s} \mathrm{mun}\end{array}$ & $\begin{array}{c}\text { Erosion potential } \\
E_{\text {corr }} \mathrm{V} \text { vs. SHE }\end{array}$ \\
\hline $\mathrm{A}$ & - & - & - & -0.394 \\
\hline $\mathrm{B}$ & 0.04 & 15 & 17 & -0.397 \\
\hline $\mathrm{C}$ & 0.014 & 15 & 17 & -0.413 \\
\hline
\end{tabular}

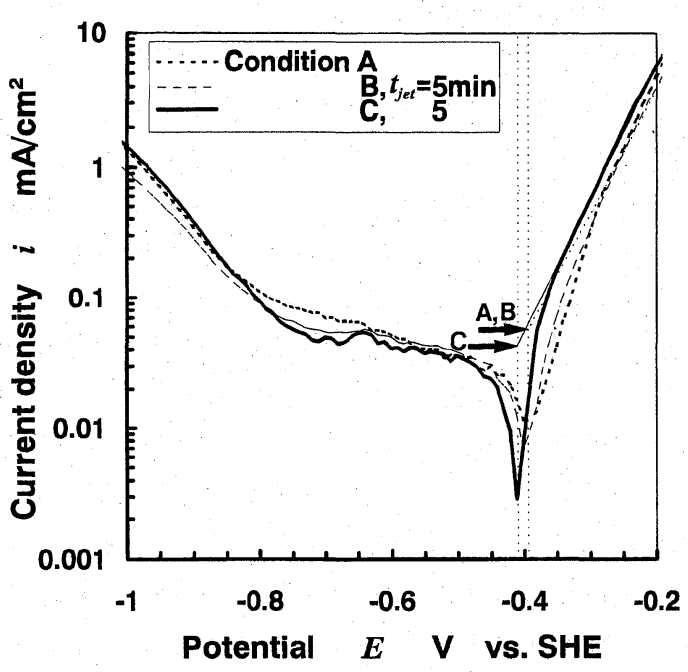

Fig. 13. Electrochemical polarization curve (S45C, $d=0.4 \mathrm{~mm}$ ).

原因としては，金属微粒子表面をアモルファス化するよ うなキャビテーション気泡の崩壊による高温スポット ${ }^{28)}$ や局所的高衝撃圧が考えられる. 表面仕上げや表面の残 留応力などによって腐食電位が変化することから, 高温 スポットによる熱処理や局所的高衝撃圧によるピーニン グ効果が耐食性を向上させているのであろう.

$$
5 \text { おわりに }
$$

キャビテーション噴流による材料試験と表面改質は, 材料力学と流体力学に跨る学際分野であり, 両分野に 抢ける的確な把握の融合が不可欠である。この解説が読 者の今後の研究の参考になれば幸いである。な振動

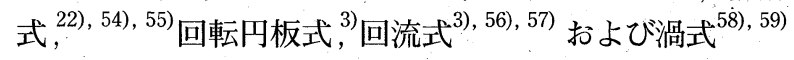
壊食試験については文献を参照されたい。

\section{参 考 文 献}

1) I. R. Jones and D. N. Edward, J. Fluid Mech., 7, 596 (1960).

2) T. Momma and A. Lichtarowicz, Wear, 186-187, 425 (1995).

$3)$ 加藤洋治, “キャビテーション”（1990）梖書店.

4) 祖山均, 伊藤幸雄, 市岡丈彦, 浦西和夫, 加藤洋治, 大場利三郎, ターボ機械, 18, 691（1990）。

5 ）例えば，ターボ機械協会水力機械委員会ポンプのキャビテ ーション損傷研究分科会, 研究成果報告書 $(1989,1994$, 1997）; 文部省科学研究費補助金（国際学術研究・共同研 究）成果報告書, 研究代表者 加藤洋治, “キャビテーシ ヨン壊食の機構とその予測法の研究”(1997).

6) A. Karimi and R. Leo, Mater. Sci. Eng., 95, 1 (1987).

7) M. K. De and F. G. Hammit, Trans. ASME, J. Fluid Eng., 104, 434 (1982).

8 ) H. Kato, A. Konno, M. Maeda and H. Yamaguchi, Trans. ASME, J. Fluid Eng., 118, 582 (1996).

9) 日本ウォータージェット学会キャビテーションジェット技 術研究小委員会報告書, “キャビテーションジェットの基 
礎と応用” (1996).

10）日本機械学会編，“P-SC 115 混相流動場と損傷に関する調 查研究分科会研究成果報告書” (1989).

11）伊藤幸雄，大場利三郎，祖山 均，緒方宏幸，岡村共由， 須藤純男, 池田隆治, 日本機械学会論文集, B-54, 2727 (1988).

12) J. P. Franc, J. M. Michel, T. H. Ngayen and A. Karimi, Proc. 2nd Int. Symp. on Cavitation, 231 (1994).

13) T. Okada, Y. Iwai, S. Hattori and N. Tanimura, Wear, 184, 231 (1995)

14) T. Okada, S. Hattori and M. Shimizu, Wear, 186-187, 437 (1995).

15）寺崎尚嗣, 和田英典, 藤川重雄, 高杉信秀, 日本ウォータ 一ジェット学会第 11 回研究発表会講演会論文集，49 (1996).

16) 祖山 均, アンドリュー・リヒタロビッチ, 門馬隆弘, 日 本機械学会関西支部第72期定時総会講演会講演論文集, No.974-1，5-39 (1997).

17) D. R. Stinebring, J. W. Holl and R. E. A. Arndt, Trans. ASME, J. Fluid Eng., 102, 481 (1980).

18) H. Kato, Y. P. Ye and M. Maeda, Proc. 3rd Int. Symp. on Cavitation Noise and Erosion in Fluid Systems, ASME, FED-Vol.88, 79 (1989).

19) B. Belahadji, J. P. Franc and J. M. Michel, Trans. ASME, J. Fluid Eng., 113, 700 (1991).

20）祖山 均, 日本機械学会論文集，B-58，3366（1992）.

21) S. Lavigne, A. Retailleau and J. Woillez, Proc. Int. Symp. on Cavitation 195, 241 (1995).

22) ASTM Designation G32-85, Annual Book of ASTM Standards, 03.02, 187 (1985).

23) A. Lichtarowicz, Nature Physical Science, 239, 63 (1972).

24) ASTM Designation G134-95, ASTM, 1 (1996).

25）小林陵二, 新井田徳雄, 佐賀紀彦, 日本機械学会いわき地 方講演会講演論文集，No.921-2，71（1992）。

26）祖山 均, 山内由章, 井小萩利明, 大場利三郎, 佐藤一 教，進藤丈典，大島亮一郎，噴流工学，13-1，25（1996）.

27）平野克彦, 榎本邦夫，林 英策，黒沢孝一，材料， 45 740 (1996).

28) K. S. Suslick, Ultrasonics, 30, 171 (1992).

29) 山内由章, 祖山均, 安達保則, 佐藤一教, 進藤丈典, 大場利三郎, 山部正博, 大島亮一郎, 日本機械学会論文 集, B-59, 16 (1993).

30) 山内由章, 祖山 均, 佐藤一教, 井小萩利明, 大場利三 郎, 日本機械学会論文集, B-60, 736 (1994)。

31). 山内由章, 浅海研悟, 祖山 均, 佐藤一教, 井小萩利明, 大場利三郎，日本機械学会論文集，B-61，785（1995）。

32) W. Kleinbreuer, "Untersuchung der Werkstoffzerstörung durch Kavitation in Ölhydraulischen Systemen" (1979) Doktot-Ingenieurs Technische Hochschule Aachen.

33) A. Lichtarowicz, Proc. Cavitation Erosion in Fluid Systems, ASME, 153 (1981).

34) A. Yamaguchi and S. Shimizu, Trans. ASME, J. Fluid Eng.,
109, 442 (1987).

35) T. Momma and A. Lichtarowicz, Proc. 2nd ASME /JSME Nuclear Eng. Joint Conf., 2, 877 (1993).

36) H. Soyama, A. Lichtarowicz and T. Momma, Proc. ASME Fluid Eng. Div. Summer Meeting, FED-Vol.236, 415 (1996).

37) H. Soyama and A. Lichtarowicz, 噴流工学, 13-2, 9 (1996).

38) 祖山 均, 山内由章, 安達保則, 佐藤一教, 進藤丈典, 大場利三郎，日本機械学会論文集，B-59，1919（1993）。

39) Y. C. Wang and C. E. Brennen, Proc. Cavitation and Gas Liquid Flow in Fluid Machinery and Devices, ASME, FED-Vol.226, 17 (1995)

40) 祖山均, 伊藤幸雄, 曹樹良, 大場利三郎, ターボ機 械, 21，215（1993）。

41）祖山 均, 李 受人, 外崎昌志, 浦西和夫, 加藤洋治, 大場利三郎，日本機械学会論文集，B-61，3945（1995）。

42）祖山均, 大場光太郎, 武田 渉, 大場利三郎, 日本機 械学会論文集，B-60，1133（1994）。

43）祖山均, 大場光太郎, 井小萩利明, 大場利三郎, ターボ 機械, 23，315（1995）。

44）大場利三郎, 日本機械学会論文集, B-63，2264（1997）.

45) A. Thiruvengadam and H. S. Preiser, J. Ship Research, 8 , 39 (1964).

46）清水誠二, 谷岡邦宏, 池上範章, 春季油空圧講演会講演 論文集，5（1997）。

47）祖山、均, アンドリュー・リヒタロビッチ, 日本ウォータ ージェット学会第11回研究発表会講演会論文集, 25 (1996).

48) J. D. Park, H. Soyama, M. Saka and H. Abe, Proc. Far East Conf. on NDT, 501 (1997).

49) 祖山 均, 朴貞道, 坂 真澄, 阿部博之, 日本材料学 会第 9 回破壊力学シンポジウム講演論文集, 184 (1997).

50) 山内由章, 祖山 均, 安達保則, 佐藤一教, 大場利三郎, 日本機械学会論文集，B-60，2671（1994）。

51) 安達保則, 祖山均, 山内由章, 佐藤一教, 井小萩利明, 大場利三郎，日本機械学会論文集，B-60，730 (1994).

52）安達保則, 祖山 均, 山内由章, 佐藤一教, 井小萩利明, 大場利三郎，日本機械学会論文集，B-60，2665（1994）。

53）祖山 均, 石川陽一, 坂 真澄, 阿部博之, 第9回キャビ テーションに関するシンポジウム講演論文集，27(1997).

54）松村昌信，ターボ機械，18，574（1990）。

55）JIS R 1615，ファインセラミックスの高温・高圧環境試験 方法 (1993).

56）エロージョン・コロージョンと利用技術編集委員会編，“エ ロージョン・コロージョン”, 215 (1987) アイピージー.

57) Y. Lecoffre, La Cavitation, Hermes, 410 (1994).

58) Y. Lecoffre, J. Marcoz and B. Valibouse, Proc. Cavitation Erosion in Fluid Systems, ASME, 133 (1981).

59) M. A. Dominguez-Cortazar, J. P. Franc and J. M. Michel, Proc. 3rd Int. Conf. on Cavitation, 43 (1992). 